\title{
Local Uses of International Criminal Justice in Bosnia-Herzegovina: Transcending Divisions or Building Parallel Worlds?
}

\author{
DEJAN GUZINA AND BRANKA MARIJAN ${ }^{1}$ \\ Wilfrid Laurier University, Canada
}

\begin{abstract}
Transitional justice mechanisms and the International Criminal Tribunal for the Former Yugoslavia (ICTY) have had only a limited success in overcoming ethnic divisions in Bosnia-Herzegovina. Rather than elaborating upon the role of local political elites in perpetuating ethnic divisions, we examine ordinary peoples' popular perceptions of war and its aftermath. In our view, the idea that elites have complete control over the broader narratives about the past is misplaced. We argue that transitional justice and peace mechanisms supported by external actors are always interpreted on the ground in context-specific ways, creating different citizens' experiences, "memories" of the war, and their respective hopes and disappointments in regards to the relationship between peace and justice in Bosnia. We suggest that analyses of the post-conflict developments in Bosnia-Herzegovina must take into account what gives the narratives of exclusion their power, and what are the objective political, social and economic constraints that continue to provide a fertile ground for their widespread support.
\end{abstract}

\section{Introduction}

In their response to the signing of the 1995 Dayton Peace Agreement, which ended the war in Bosnia-Herzegovina, Antonio Cassese, the first president of the International Criminal Tribunal for the Former Yugoslavia (ICTY), and Justice Richard Goldstone, a Prosecutor at the ICTY, noted that:

Justice is an indispensable ingredient of the process of national reconciliation. It is essential to the restoration of peaceful and normal relations between people 
who have had to live under a reign of terror. It breaks the cycle of violence, hatred and extra-judicial retribution. Thus Peace and Justice go hand-in-hand (ICTY, 1995).

Firmly asserting the linked nature of peace and justice, Cassese and Goldstone outlined many of the hopes of the international community for the ICTY and for its role in the Bosnian peacebuilding process. Moreover, the current president of the ICTY, Theodor Meron, noted in his annual report that the ICTY has pioneered a new world order "in which the question is not if but when and where they (perpetrators) will be called to account" (ICTY, 2012). In contrast to these sentiments, twenty years since The Hague Tribunal opened its doors (1993), most of the local population in Bosnia-Herzegovina (hereafter Bosnia) seems to be united in its belief that ICTY did not live up to its high expectations. The aim of this article is to analyse this empirical puzzle of the emerging gap between the international praises of the role of ICTY and Transitional Justice (TJ) mechanisms in contributing to peace and justice in Bosnia and the disappointment and resignation, but also increasing lack of interest, of the Bosnian population in the reconciliatory potentials of ICTY and TJ in bringing Bosnian communities together.

The article demonstrates that, while the ICTY could rightly be seen as a pioneer of a new normative trend of supranational prosecutions of war crimes and human rights violations, its contribution to the reconciliation and social reconstruction on the ground has been limited. We argue that transitional justice and peace mechanisms supported by external actors are always interpreted on the ground in context-specific ways, creating different citizens' experiences, "memories" of the war, and their respective hopes and disappointments in regards to the relationship between peace and justice in Bosnia. Contrary to the expectations of the international actors and scholars arguing in favour of TJ mechanisms, analysis of the post-conflict developments in Bosnia shows that local actors have yet to come to terms with the historical narrative that would transcend ethnic divisions. In other words, Bosnian local communities continue to be segregated both physically and mentally from each other.

The disconnect between the internationally supported goals of reconciliation and the "local" acts of contestation and communal citizenship practices is most visible in the popular perceptions of war and its aftermath in two major Bosnian cities: Sarajevo and Banja Luka. Whereas before the war these cities, together with Mostar, represented the multiethnic and multicultural centres of Bosnia, after 1995 they emerged as symbols of division and mutually contradictory nation building projects. The different interpretations of the history of the war are cogently captured by a member of one community organization in Banja Luka: "When it comes to the past, the war, the consequences of the war there exist two parallel worlds, one with the center in Sarajevo and the other in Banja Luka" (Personal communication, June 7, 2012). Through the evaluation of TJ literature, but also drawing on field work and interviews conducted in Sarajevo and Banja Luka in June 2010 and May and June of 2012, this article examines the contested ways in which the views of justice have been shaped by local Bosniak and Serbian populations since 
1995. The interviews were conducted primarily with key informants, namely local bureaucrats working for the international organizations in Bosnia, civil society representatives and activists engaged in issues of reconciliation and peacebuilding.

This article proceeds as follows: we examine the international approach to peacebuilding within the broader socio-economic context in Bosnia. Then we turn to the scholarly debates about the contribution of external justice mechanisms, particularly focusing on the ICTY. Finally, we review the overlooked importance of ethnic identity politics in shaping responses to the overall approach of transitional justice. We also turn to specific examples of the ways in which the local population responded to the ICTY ruling and how it deals with the legacies of war. We then examine issues pertaining to peace and justice from the ground up by focusing on local concerns raised about living with the legacy of the conflict. We argue for a more grounded analysis of transitional justice mechanisms, an analysis that incorporates local contexts and the process of the localization of global norms and goals (Acharya, 2004). Thus, we argue for a particular focus on the ways in which justice and peace are interpreted, supported, or contested in the local social and political space and emphasize the agency of the local population in appropriating TJ mechanisms according to their own specific needs rather than in the interests and goals of international policy makers.

\section{A Blueprint for Dayton Bosnia-Herzegovina}

The 1995 Dayton Peace Agreement has been successful in bringing about a cessation of hostilities and violence. At the same time, it has also been criticized for further cementing the divisions in Bosnian society by ensuring that the three constituent peoples (Bosniaks, Croats and Serbs) are represented in state institutions and leadership positions according to the rigid rules of ethnic representation. Moreover, Bosnia emerged as a federation comprised of the Bosniak/Bosnian Croat Federation of Bosnia and Herzegovina and the Bosnian Serb-led Republika Srpska (RS). The Peace Agreement simply legitimized the structures that emerged from the war by incorporating them into the Bosnian Constitution.

The international community has tried to provide a balance between the differing ethnic interests, most visibly through the Office of the High Representative (OHR). It has also sought to ensure compliance with the ICTY and stressed the importance of addressing war crimes that were committed during the conflict. The active role of the international community in Bosnian politics and indeed in engineering the Bosnian state, however, has led some Western scholars to argue that as an internationally supported state, Bosnia has become an "inverted state" (Chandler, 2009, p. 74), or a state that is overly shaped by external agendas rather than by local processes. In his work on Bosnia and other post-conflict states, Oliver Richmond has argued that such a top down approach to peacebuilding has resulted in "virtual peace" 
on the ground (2008, p.440). Richmond argues that many of these externally created institutions are disconnected from citizens and from the dynamics on the ground. Yet, despite the growing critique, the external approach to peacebuilding is also mirrored in the efforts of the international community to bring about transitional justice to the region, and thus connects peace with justice as the only viable alternative to the current state of affairs of the continuation of war through the means of politics. But to what extent can we expect externally driven processes of peacebuilding to resonate in local contexts?

The original intention of external state builders in Bosnia was to compensate for the overtly rigid power-sharing arrangements in the political field by creating powerful constitutional and institutional arrangements that would (in principle) allow for the development of civil society and human rights. According to this logic, those interested in politics would enter the political arena with explicit and somewhat contradictory aims of simultaneously building democracy, on the one hand, and defending one's national interest, on the other. Those disinclined to enter politics would have other venues open to them such as joining any of the externally-financed civil society organizations that were supposed to counter-balance the paralyzing effects of various power-sharing arrangements in the respective countries. The hope was that through the active engagement of the international community (IC), some of the ethnic aspects of power-sharing arrangements would eventually be replaced with more integrative institutions along the civil society model allowing the pursuit of TJ to be accepted across the ethnic boundaries.

This, however, never fully materialized. Instead, the political arrangement and institutionalization of power sharing, on one side, and the failures of the reversal of ethnic cleansing on the other, have created a particular post-war demographic reality of the current Bosnian state where most of the regions are clearly dominated by one ethnic group over the other. In addition, and often pointed to as one of the reasons for the continuing hold of the nationalist narratives, is the Bosnian economic reality whereby the unemployment rate is at $28 \%$ with youth unemployment estimated to be twice that rate (World Bank, 2012). Moreover, according to the latest Transparency International Report (2012), Bosnia is one of the most corrupt states in Europe: its annual index of corruption perception ranks Bosnia as 72nd out of 176 countries in the world (Jukic, 2012). Of course, the reality behind these numbers points towards the systematic nature of Bosnian corruption; that is the fact that corruption is one of the pillars of the Bosnian economic and political system.

In summary, the unclear role of the IC, the never-ending political crisis of the Bosnian state, its economic and social uncertainties, rising poverty, state-wide corruption, and demographic failures of multiethnic integration, all represent the context within which Bosnian narratives co-exist. While we focus here on nationalism and a politics of reconciliation as seen through identity lenses, we fully recognize that identity narratives never exist in a vacuum. Rather, they are malleable and change in response to the day-today Bosnian economic, social and political realities. It is only within this 
broader context that we assess the initial ICTY goals of individualizing criminal responsibility, legitimizing a historical record and contributing to reconciliation; that is we assess how these goals have been appropriated and transformed into hotly contested, essentialized and ethnicized arguments over what is "ours" and what is "theirs," who are the victims and who are the perpetrators, and over the very nature of the war itself, whether it was a civil war or an act of aggression and genocide against the Bosniak population.

\section{Transitional Justice Remedies for Bosnia's Symptoms}

The competing narratives over the war in Bosnia revolve around whether Republika Srpska is a legitimate entity or not. In the eyes of Bosniaks, it is not, for they were victims of genocide; in the eyes of the Bosnian Serbs, Republika Srpska is a legitimate expression of their need to protect themselves against the potential physical threat of other communities in Bosnia. In order to support this claim, the 1992-1995 war in Bosnia is being connected to the Bosnian Serbs' horrific experiences during WWII. The way in which these competing narratives are posited against each other leaves little room for compromise. More than seventeen years after the signing of the Dayton Agreement, these narratives still hold sway over both local populations and their respective elites.

Passionate debates over the question of who is right and whose justice should be served are fully understandable. After all, at the heart of this debate is the question of moral and legal responsibility for the crimes committed in one's national name. The general premise of TJ mechanisms, well summarized by Cassese (2004), has been to individualize the guilt and stop perpetuating divisive categories of framing the conflict exclusively in group terms. According to such an understanding, Cecile Aptel observes, "it is reasonable to assume that criminal justice, including international and hybrid jurisdiction, can contribute to the reconciliatory process in divided societies, as long as significant portions of all communities accept the legitimacy of the accountability mechanisms" (2011, p. 180). In Bosnia this is precisely the issue because accountability mechanisms, such as the ICTY and domestic trials, are increasingly seen as political theatre of the absurd rather than the mechanism that would allow the truth about the war to be discovered and shared by members of different Bosnian ethnic groups, ultimately leading to their mutual recognition and reconciliation. Thus, Bosnian experience with TJ seems to go against both international policy makers' expectations and the scholarly literature's claims that the need to address past violence is a necessary step in ensuring sustainable peace (Leebaw, 2008, p. 96).

More recently, Lara J. Nettelfield (2010) has further elaborated on the significance of TJ for postwar states. In her book, Courting Democracy in Bosnia and Herzegovina: The Hague Tribunal's Impact in a Postwar State, she focuses exclusively on the role of the ICTY and hybrid jurisdiction in Bosnia. Even though she appears to emphasize only the legal elements of TJ, 
her main conclusion is that the real benefit of The Hague process and other forms of TJ is their contribution toward "positive democratic development inside Bosnia," and particularly the "creation of new postwar identities based on the rule of law and participation" (Nettelfield, 2010, p. 15). Drawing upon the work of Mark Drumbl, she is doubtful that retributive and deterrent goals of domestic justice can be easily replicated in the context of international criminal law. After all, the central tenets of international criminal law are: to uncover the truth about the past atrocities, punish perpetrators and help victims; provide the rule of law, support reconciliation, and serve as deterrent for future crimes (Nettelfield, 2010, p. 10). While fully accepting Drumbl's caution about retribution and deterring potentials of international justice, Nettelfield argues that the extra-legal rationale for international tribunals still stands.

Thus, it would seem that Nettelfield departs from the general thrust of the TJ literature, while still endorsing the TJ mechanisms. For her, the broader normative impacts of $\mathrm{TJ}$ mechanisms are more important than some other goals of international criminal law. That is, the justification for international prosecutions lies in "the messaging value of punishment to affirm respect for law, reinforce a moral consensus, narrate history and educate the public" (Drumbl, quoted in Nettlefield, 2010, p. 11). From this perspective, Nettelfield concludes that "the work of court encouraged political participation by representatives of family associations and civil society groups who might otherwise have lacked legitimacy; it provided them and elites with a language about accountability and, in some cases, a set of tools, namely, law, with which they could lobby for forms of redress" (Nettelfield, 2010, pp. 273274). In other words, even though Bosnians failed to receive justice, they received democracy (or, at least, they started moving in that direction), and through the work of international and hybrid courts certain forms of civic and political engagement have developed that otherwise might not have been possible. From a policy perspective, this conclusion radically steps away from the conventional understanding of TJ and yet still heavily relies on the same assumptions about the possibilities of $\mathrm{TJ}$ to contribute to reconciliation on the ground.

Jelena Subotic (2009) offers yet another insight about the unintended consequences of TJ mechanisms. She argues that TJ institutions have become very popular in addressing past abuses in post-conflict societies, while at the same time such states "use these mechanisms to achieve goals quite different from those envisioned by international justice institutions and activists" $(2009$, p. 6). Thus, she recognizes yet another layer of the top-down approach in bringing justice to post-conflict societies. While the mainstream literature evaluates the workings of the international agencies, she believes that between the local populations and external state builders, local elites have the power to filter policies in ways that are clearly not foreseen by the International Court of Justice or any other international organizations dedicated to bringing justice to these countries. Thus, Subotic insists that analysts should not only focus on whether or not states comply with a TJ framework, but also how and 
why they may comply.

Subotic proposes an analytical framework that is based on distinguishing between four major state and societal coalitions: true believers who fully support the normative principles of TJ; norm resisters; instrumental adapters; and international norm promoters. Her argument is very simple but effective -in situations when norm resisters and instrumental adopters are stronger than true believers, the normative and institutional compliance will take the forms that are unanticipated by the international promoters (Subotic, 2009, pp. 6-8). In other words, various coalitions within a post-conflict state will engage in appropriating $\mathrm{TJ}$ initiatives according to their own respective political objectives.

Subotic's contribution to transitional justice literature lies in pointing out some of the unforeseen consequences of TJ initiatives. But, there must also be a critical examination of the key justification of transitional justice institutions: they create a historical record of the systematic violence that stands in counter to the denial of the extent and impact of the violence (Leebaw, 2008, p.107). The lack of an accepted historical record of the events in Bosnia during the conflict is evident from an examination of the speeches of various ethnic leaders, the divided curriculum and the national subject of history, and through discussions on the ground which can often reveal the ethnic group which the story represents. The insight gained from Subotic's research is that far from coming to a single version of events the various elites have used the past to pursue their own political goals. Isabelle Delpla summarizes the issue when she states that, "judiciary truth established in The Hague is far from achieving public acknowledgment in Bosnia" (2007, p. 216). Rather than creating a historical record about the conflict what has resulted in Bosnia is a use of the past by elites to play to their own ethnic group in order to pursue nation building projects. This is further shown by the fact that without international pressure there is also an unwillingness to prosecute members of their own community (Zoglin, 2005). Hence, the various mechanisms including the ICTY and ICJ have not been able to bring out an agreed upon record of the Bosnian past. Any effort to do so was, and still is, thwarted by various local actors' countermoves, or in Subotic's terminology, by the countermoves of norm resisters and instrumental adapters.

However, despite the challenges facing the approaches to peace and justice at the political level, some scholars have argued for caution on purely principled grounds of the incompatibility between reconciliation and punishment. They doubt that it is possible to expand the legal mandate of TJ to include reconciliation if the ultimate goal of justice is the prosecution of war crimes (Fletcher and Weinstein, 2004, p. 30). Yet, despite reconciliation not being central in the UN resolution that created the ICTY (Fletcher and Weinstein, 2004, p. 37), it became central in the subsequent interpretations of the role of the ICTY. In addition, Vanessa Pupavac suggests there is a darker side of internationally supported policies of reconciliation: "War crimes tribunals and truth and reconciliation commissions are championed as political therapy, facilitating closure for traumatized nations" (2004, p. 
378). Rightly critical of the approach of treating the post-violence state as a mentally unfit patient, Pupavac shows that such an approach to TJ simply puts the finger of blame on the local population itself. Similarly, Chandra Lekha Sriram argues that "In particular, the very institutionalisation of these processes [TJ mechanisms] means that they may seem, or actually be, disconnected from the individuals and societies they are designed to benefit, or be viewed as externally imposed and illegitimate by some of the putative beneficiaries" (2010, p. 290).

So what is the state of reconciliation in Bosnian society? Valery Perry (2009) rightly notes that "reconciliation" is a word rarely mentioned in good faith in Bosnia. In her survey of reconciliation processes, she divides them into the following tracks: a non-governmental reconciliation (such as the incorporation of the experiences from other countries through the work of the so-called "conflict resolutionaires," mediation efforts sponsored by the IC, the Association of Citizens-Truth and Reconciliation); research, training and education; and official governmental reconciliation. However, despite identifying certain progress in these areas, the overall conclusion is hardly optimistic as the principles of the zero-sum game are as prevalent in the sphere of reconciliation as they are in the more traditionally perceived world of politics (Perry, 2009). Nevertheless, the question of the underlying causes for the failures of $\mathrm{TJ}$ cannot and should not be looked at only from the viewpoint of the Bosnian zero-sum game. Such understanding puts too much emphasis on the role of the local elites as primarily responsible for the failures of TJ. The underlying assumption is then that if only there were more enlightened political elites in Bosnia TJ mechanisms would work well.

As already discussed, Subotic clearly outlines how domestic elites have hijacked the TJ processes. However, she relies too heavily on insights from the rational choice approach to collective action problems, focusing exclusively on the initiatives of Bosnian ethnic and civic entrepreneurs. According to this view, various moves and counter-moves of ethnic representatives ultimately lead to attracting necessary support for their respective political agendas. The extent to which they are successful also represents the extent to which they are in charge of the collective action problem; that is, they are in a position to impose or attract members of their respective local communities to share and support their political views on the causes of and possible solutions to the crisis in the Bosnian society.

In our view, the idea that elites have complete control over the broader narratives about the past is misplaced. This elite centered view corresponds to what Rogers Brubaker refers to as the "elite manipulation" analysis of ethnic politics (1998, p. 289). Brubaker argues that the elite dominance perspective is limiting because it brushes over the complex process of the constitution of interests and their role in the identity formation. Elites cannot simply set agendas dominated by their own interests. Their ability to do so is shaped by the issues that resonate within their communities and a particular community's understanding of its relevant identity. For Brubaker, the "elite manipulation" argument misses the variation in "conditions of responsiveness" 
or the reasons why in certain areas and in certain communities inflammatory politicians succeed with their nationalist narratives (1998, p. 291), and in some others they do not. In relation to the Yugoslav conflicts, he emphasizes the importance of already existing conditions of unofficial narratives about past persecutions that influence further the ways in which individuals respond to various forms of elite manipulations.

The same argument can be adjusted to explain why international elites are not able to impose a particular order or their own interests on local populations. Roger Mac Ginty (2011) aptly describes the interaction between the "internationals" and "locals" as being hybrid in character, where international actors are not only trying to influence local actors, but are being influenced equally in return. International actors involved in the TJ processes become involved in the various narratives, often because their actions have unintended consequences (for example, being seen as expressing support for one side over the other). More importantly, Mac Ginty stresses that local resistance to external agendas can be both positive and negative, and that sectarian and selfish interests motivate some acts, though not all. Regardless, he notes that, "in some cases, resistance leads to a better form of peace: a peace that is more comfortable and sustainable for the communities that must live that peace. A great difficulty is that many international actors and perspectives are unable to accept such hybrid forms of peace as "peace" (Mac Ginty, 2011, p. 212).

Following the lead of Brubaker and Mac Ginty, we argue that the local context is a two-way street in which ordinary citizens are not simply puppets passively responding to entrepreneurial actions of various elites. They do have, and exert their own agency, however, not always to the liking of those believing in the principles of TJ and liberal peace building. Moreover, in the context of the competing narratives over the recent past in Bosnia, neither domestic nor international actors can impose simply what they deem as legitimate accounts of the war. Local populations are actively engaged in creating and disseminating stories about $\mathrm{TJ}$ on their own to the extent that such narratives provide meaning to the their actions.

\section{A Ground Up View of Peace and Justice in Bosnia-Herzegovina}

Why do TJ mechanisms fall short of expectations? Paige Arthur (2011) argues that $\mathrm{TJ}$ concepts and policy approaches do not take seriously enough the role that our identities play in channelling our actions. Following Fearon and Laitin, she reminds us that ethnic identities are different from other social identities "because they are constructed around the idea of descent, as well as social and biological reproduction" (Arthur, 2011, p. 273). As such, they are composed of "cultural attributes" (religion, language, custom, myths), neither of which could be easily handpicked by individuals (Fearon and Laitin, 2000, p. 848). Arthur does not dismiss the individualist constructivist arguments; nevertheless, she points out that there are limits to which 
identities can be constructed. This, however, has important consequences for our understanding of TJ, for, as Arthur explains, ethnic violence can never be reduced to political violence (2011, p. 273). Accordingly, an overtly formulaic approach that shies away from the problem of the salience of ethnic identities is bound to fail when TJ measures become translated by local populations to fit their preconceived notions of identity.

In similar fashion, Will Kymlicka maintains that the concept of TJ is very closely tied to a civic understanding of nation building that assumes that all citizens, irrespective of their cultural differences, share the same vision of political community. However, despite the strong support for such a model of political community both among the scholars and external policy makers, this model is quite often untenable in societies where more than one cultural community shares the same space and memories (Kymlicka, 2011, pp. 303307). Under such conditions, the members of other communities quite often perceive the support for political community that will transcend cultural and ethnic boundaries as an open policy of assimilation. In more extreme cases, this will lead to open ethnic conflicts where all kinds of mass crimes are committed in the name of one's nation. Thus, in the context of post-conflict development, divided societies quite often perceive conventional polices of so-called citizenization with distrust, for they can always be interpreted as more beneficial to the majority or the dominant group in such a state. In other words, a purely civic form of nationhood quite often (whether inadvertently or not) leads to clashes over the issues of ethnicity (language, identity, customs, religion, memories of the past). Overall, the politicization of ethnic and religious ties shapes citizens' responses to various TJ mechanisms. Engagement with TJ mechanisms is shaped by in-group mentalities according to which individuals are primarily wishing to represent one's own community concerns and grievances. In this context, storytelling emerges as one of principal ways to interpret recent past events, and in the process, strengthen the boundaries between members of one particular ethnic group and those of the other.

The case of Bosnia is symptomatic in this regard; two examples, namely, the Oric trial and the correct number of the war casualties in the Bosnian war, illustrate the ways in which the norms and institutions of TJ were appropriated for the purposes of further delineating the boundaries between the Bosniak and Serb communities in Bosnia. But, why focus on these two cases: the Oric trial and the body count? From the perspective of liberal peace building and $\mathrm{TJ}$ literature, they can be dismissed in favour of some other accounts of successes and failures of TJ in Bosnia. In that respect, the Oric case is particularly problematic given that the Bosniak authorities closely cooperated with the IC and thus were actively engaged in Oric's surrender. In support of this view, we cite a very rich literature dealing with some of these issues, including, Delpla, Bougarel and Fournel (2012), Nettelfield (2010), and Clark (2009). Nevertheless, we do not deal with the technical aspects of the mechanisms of TJ, but rather with the perceptions of these efforts on local populations and how they understand it. As Marc Howard Ross explains: 
In long-term intransigent conflict, strong threats to identity are an essential part of the conflict dynamics, and any efforts to defuse such a situation must take seriously the stories that participants recount, and the perceived threats to identity. The point, after all, is not whether participants' accounts are true or false from some objective point of view but that they are meaningful to the parties involved. (1997, p. 64)

From this perspective, the Oric case and the number of war casualties are central to local Bosniak and Serbian efforts to deal with the legacies of the war, and how to make meaning of the war. This aspect in no way should be understood to be the replacement for the debates about individual responsibility of those involved in war crimes, or of the role of impartial institutions in making reconciliation possible. It simply recognizes local communities' efforts to deal with the past that do not correspond necessarily to the internationally prescribed political objectives for Bosnia. Without understanding them on their own merit, we simply cannot see how a more integrative counter narrative can be developed successfully.

The Oric case was the first case that tested Bosniaks' trust in the work of the ICTY; for the first time, it was one of their own that was on trial. Naser Oric was a Bosniak war commander in the area around Srebrenica. The NATO forces arrested him in 2003 for the crimes committed against the Bosnian Serbs in the Serbian villages surrounding Srebrenica in 1992 and 1993. Despite the Bosnian government's support for Oric's arrest and his transfer to The Hague, the action provoked many Bosniaks to accuse The Hague Tribunal as playing the ethnic balance game (Kebo, 2005). Thus, for the Bosniak side, such an arrest was, in the words of one of the representatives of the NGO Mothers of Srebrenica, a shameful act because his only crime was, in the words of many, to "defend his own people." Others in the Bosniak community have argued that Oric's crimes, the killing of seven Serbs, are far less serious than the offences committed by thousands of former Serb soldiers, none of whom have been indicted. On the other side, as a journalist reported at the time, a local Serb, and the head of the association of war invalids in a Serbian village, Bratunac, had said, "Naser's departure to The Hague proves that justice will reach everyone. We are beginning to believe a bit more that The Hague is not biased, that it is not arresting only Serbs, but all those suspected of committing crimes" (Kebo, 2005). In July 2006, Oric was sentenced to two years in prison to be immediately released for time already served. On his way back from The Hague, Oric enjoyed a hero's welcome home, which once more indicated to local Serbs that the ICTY is biased against them and that it could not be trusted (Subotic, 2009, p. 131). Moreover, as Subotic has poignantly described, the most controversial aspect of the entire case is the judicial justification of the sentence, according to which the abysmal conditions in Srebrenica "led to such a breakdown of law and order that Oric could not be held accountable for the crimes committed by his troops" (2009, p. 130).

So, was justice served in Bosnia? Many scholars and policy makers seem 
to think so by emphasizing the historical role that ICTY has played. But people in Bosnia are resigned in their evaluation of the ICTY's lofty goals and achievements, albeit for different reasons. Fadila Memisevic, President of the Society for threatened peoples in Bosnia-Herzegovina, was recently quoted by Radio Free Europe as saying:

We were naïve that the tribunal will put an end to this evil [of mass atrocities, mass rapes, crimes against humanity, and genocide during the war], and yet we still keep moving in circles. This is not a Nuremberg Trial with clear understanding of who is the defeated side in the war. The worst of all, those who were sentenced can now, after they are released from prison, assume their political careers. ... This is absurd. The [ICTY] verdicts do not fit the crime, and I don't think that the justice has been served [in Bosnia]. (quoted in Dzenana Halimovic, October 15, 2012)

Against Memisevic's statement, we can quote the words of Janko Velimirovic, Director of the Centre for investigating war crimes in Republika Srpska:

We have the result that [among the accused in The Hague] 58\% are Serbs, 25\% Croats and $9 \%$ Bosniaks. This has created a particular understanding of the war in the public that is very hard to change and that does not reflect the reality. The available proof and documentation clearly do not support the percentages [of guilt] that are emerging out of The Hague Tribunal. (quoted in Dzenana Halimovic, October 15, 2012)

The two narratives once again reflect the different perspectives and struggles in post-war Bosnian society. The perspective of Memisevic brings out the view of many Bosniak victims' groups that do not feel that the prosecutions reflect the punishment required, given the scale of the violence during the war. Velimirović's view is reflective of the Serb victims' groups who do not feel that their story has been heard and addressed. Both of these concerns, even though are very similar in the need for the perpetrators to be held responsible, unfortunately have been subsumed by broader narratives. These broader narratives are the delegitimization of the Republika Srpska's existence because of the lack of widespread punishment for the scale of the violence committed by those who created this entity. Bosnian Serbs tend to group around the narrative of the defense of the legitimacy of Republika Srpska's existence and argue that the court in The Hague does not equally address the crimes against the Bosnian Serbs. Ultimately, the victims' concerns for justice are being fused with radically different Bosniak and Serb nation building goals and visions for Bosnia-Herzegovina.

Evident in the reactions surrounding Oric's trial, and in subsequent discussions over whether or not justice was served, is the link between the two narratives and the opposing perceptions about Srebrenica. From the very beginning of Dayton Bosnia, Bosniaks have shared an understanding that they were victims of genocide. Subotic rightly asserts that this was the reason why they were much more interested in the genocide case in front of 
the International Court of Justice (ICJ) than in the individual cases before the ICTY (Subotic, 2009, p. 154). The genocide conviction was first passed in 2001, when the ICTY clearly stated in its verdict against the Bosnian Serb commander Radislav Krstic, "[B]y seeking to eliminate a part of the Bosnian Muslims [Bosniaks], the Bosnian Serb forces committed genocide. They targeted for extinction 40,000 Bosnian Muslims living in Srebrenica, a group that was emblematic of the Bosnian Muslims in general" (Prosecutor vs. Krstic, 2004). This ruling was hailed as historic by the Bosnian media. It also created optimism that a similar ruling would soon follow in the case of Bosnia vs. Serbia at the International Court of Justice. The hope was that by winning the genocide case against Serbia, the Bosnian war should be finally redressed as a war of aggression and genocide against Bosniaks, which would then have necessitated the abolition of Republika Srpska and Serbian reparations to Bosnia. In other words, what could not have been achieved during the Dayton negotiations could have been finally achieved through the Court ruling.

However, in February 2007, the ICJ issued a ruling that cleared Serbia of direct responsibility for the genocide and any complicity in the genocide that happened between 1992 and 1995. Also, the ruling reiterated the ICTY decision that the only confirmed case of genocide in Bosnia is the one committed by the Bosnian Serb forces in Srebrenica (Goldstone \& Hamilton, 2008). Finally, as much as the Bosniak intellectuals and leaders experienced the ICJ's ruling as an insult, Serbia's authorities were relieved. The decision vindicated them and effectively undermined the Bosniak claims that the war was one of Serbian aggression and genocide against Bosniaks.

Thus, whether justice has been served by the Oric case and others depends on which group representatives are consulted. Overall, there is widespread agreement on the part of the local population that the ICTY has done little to support or inspire reconciliation between the communities. In his analysis of the impact that the ICTY has had on "societal peace," James Meernik finds little support for the argument that the ICTY has had a positive impact on the society. He finds that " $[\mathrm{M}]$ ore often than not, ethnic groups responded with increased hostility towards one another after an arrest or judgment" (Meernik, 2005, p. 287).

Finally, how many people died in the Bosnian war? During the war, the international media reported the loss of more than 200,000 lives. This figure was based on the UN Expert Commission's Report on war crimes in Bosnia that was released in 1994. However, even before the release of the report, similar figures were freely circulating in the media without journalists apparently ever bothering to substantiate them. After the war, these figures were further supported by claims that 160,000 victims were Bosniaks, 30,000 Croats, and 25,000 Serbs (Srebrenica Genocide Blog, http://srebrenicagenocide.blogspot.ca/). It is no wonder then that everybody was caught by surprise when an NGO based in Sarajevo, the Research and Documentation Center, first published its data (the so-called Book of Dead) on the number of dead in the war. The Center confirmed that 95,949 people were killed in 
the war (60 percent soldiers and 40 percent civilians), a much smaller figure than the one usually circulated in media reports following the war. According to the ethnic demographic of the dead, 64,036 were Bosniaks, 24,905 Serbs, and 7,788 Croats (that is, around 66 percent of all victims were Bosniaks, 25 percent were Bosnian Serbs, 5 percent Croats, and 2 percent Other). At the same time, the statistics are rather different for the civilian casualties: more than 80 percent of civilian victims were Bosniaks, 10 percent were Bosnian Serbs, and around 5 percent Bosnian Croats (The figures are regularly updated by the Center. They can be accessed on the Center's website: http:// www.idc.org.ba/). ${ }^{2}$

In December 2005, when the first results of the Research and Documentation Center became public, the Bosniak political and intellectual elites publicly attacked the Center's projects on the following grounds: methodology, integrity of the people involved in it, sources of finding, and so on (the Center is internationally sponsored, like any other NGO in Bosnia). What was hard for the Bosniak leadership to accept was that the head of the project was a Bosniak himself, Mirsad Tokaca, whose Center works under the slogan "Truth now, peace forever". Of course, the rationale for dismissing the work of the Center has been the fear that a decrease in the reported numbers of dead will undermine the official narrative that the war against the Bosniaks was genocidal in its character and thus that the Republika Srpska, as an illegal state, an illegitimate outcome of such a war, should be abolished. Of course, this is exactly how this was interpreted by the Bosnian Serb (and also Serbian) media. However, as Mirsad Tokaca has aptly explained: "Genocide is not a question of numbers; it is the matter of the identity of the victims" (quoted in Subotić, 2009, p. 155). The figures do support both the fact and the consequences of the Bosnian Serb policies of ethnic cleansing towards Bosniaks. After all, more than 80 percent of the civilian casualties are identified as Bosniak.

The debates about the character of the war, the right number of dead, and the Oric case show how the lack of trust between local communities continues to shape the content of their respective narratives. At the same time, the inability of the IC to address these narratives on their own terms leads to seemingly out of touch approaches by donors, especially in the context of issues of reconciliation. This is clearly evident in the case described below where the well-intentioned push to create cross community linkages between youth disregarded the reality of a post-war environment. As a member of a religious organization in Sarajevo stated:

They [international donors] were insisting on a project that would bring children from a primarily Bosniak town and to get them to go to stay with a Serb or Croat family in another town. This was unacceptable to the parents and we had to explain the extent of these fears. Maybe you can do this type of thing in a society which has not experienced conflict but you cannot do that here. The context is simply different. (Personal Communication, May 26, 2012)

In the end, the organization did not receive funding because they were not 
willing to comply with donor specifications. From the donor's perspective, this might be hard to understand. After all, Bosnia has experienced no reoccurrence of violence since 1995. However, as both Sarajevo and Banja Luka's interviewees have pointed out, the sense of fear and resentment still continues to shape interactions between individuals (Personal communication, May/June, 2012).

Through their lyrics, young musicians from the Bosniak and Serb communities have attempted to address these fears and to show their understanding of the other community's perspective but they still find it difficult to deal with the level of hate speech about the other that has become normalized (Karabeg, 2012). Two musicians in particular, Adnan HamidovicFrenkie, from Tuzla, and Djurica Stula- grof Djuraz, from Banja Luka, believe that hate speech has been misunderstood as patriotism by younger generations, but also as the politicians' way on both sides to avert the public attention from the dire economic reality. Djurica concludes that, while he does not consider himself a separatist, the continuation of inter-communal distrust and fear will eventually lead to the division of the country as the only viable option.

Adnan, in his song, "Letter for Milan", tackles the subject of the extent of the fear and anger between the Bosniak and Serb communities (Hamidovic, 2012). The song is written to a Bosnian Serb, Milan, and touches on such sensitive topics as the labelling of the Serb community as a "genocidal nation" by some of his Bosniak compatriots. Perhaps most striking in his lyrics is his frank discussion of how there are always two different perspectives on the causes and consequences of the Bosnian war: "our story" and "their story". He acknowledges the danger that within his own Bosniak community he might be seen as somebody who turned his back on them by simply tackling the issue of reconciliation in his songs. Frenkie raps that it is hard even to attempt to reconcile with the other because "this will be met with your own community ostracizing you," while there is also no guarantee that the other will return the gesture. Thus, despite their civic engagement the two musicians are fully aware of how relevant and powerful the group narratives of separation are in shaping interactions between the youth.

Similar sentiments are expressed by a young activist from Banja Luka who argues that there is a "Sarajevo story" which, she explains, is the version of the past perceived to be favoured by the Bosniak population and often espoused by Bosniak politicians (Personal communication, June 7, 2012). She has found that she is distrusted in her hometown because of her contacts with groups from Sarajevo that keep insisting on their work on Srebrenica. The connection between someone from Republika Srpska to the "Sarajevo story" is not readily accepted and vice versa in the case of an inhabitant of Sarajevo. As a civil society member from Sarajevo points out, "I think we lack people who are strong enough not to pay attention to how they will be judged for their actions in their respective communities... As it stands right now, the pressure and judgement of the community is paramount" (Personal communication, May 30, 2012). 
In other words, while there are those who are ready critically to address the issues of the past, or reconcile with their former neighbours, it does not necessarily follow that this often-romanticized resistance on the ground against the domineering practices and narratives of exclusion is widespread or supported. Nor does it follow that such efforts at reconciliation are solely being restrained by nationalist politicians. The situation on the ground is more complex. While there is certainly potential for overcoming the divisions and for many individuals to connect with one another, there are still strong feelings about the past in many parts of Bosnia.

Stef Jansen (2007) points to the role of pre-war local power dynamics, demographics, geography and history in shaping the experience of the violence. Jansen argues that this means that not only do people remember the conflict in subjective ways but that judicial institutions and scholars need to be aware of these dynamics (2007, p. 207). Janine Natalya Clark (2009) also points this out in her research with ordinary Bosnian citizens, some of whom wanted a broader responsibility to be addressed in relation to the crimes committed in the past. Some individuals, particularly those in Srebrenica and Potocari, felt that both Serbian and Dutch governments should be held responsible for the events that occurred there (Clark, 2009, p. 472). Hence, the idea of widespread reconciliation does not seem to be supported by Bosnian experience. It also shows that whatever success can be achieved in dealing with the past in Bosnia it is going to be far from uniformly supported because the conflict was more prominent in particular areas with shifting narratives of blame and guilt.

To summarize, the above discussion has sought to connect two key arguments. The first is that while there are organizations and local actors in Bosnia focusing on reconciliation, their work is not always widely supported within their own communities. The post-war narratives that have emerged in the two main Bosnian cities keep members of various Bosnian communities separated from each other. This leads to the second point: without the widespread support of the communities themselves for broader reconciliation, little reconciliation can be achieved. Externally supported and top down approaches to reconciling peace and justice in Bosnia have had little effect.

\section{Conclusion}

International efforts to stop perpetuating divisive categories of framing the responsibility for the Bosnian conflict exclusively in collectivist categories have had only limited success in the Bosnian context. In a somewhat paradoxical fashion, in the few cases when TJ seems to have been working, this has not been so much because of its restorative or democratizing potential; rather, various local civic and political organizations have always been ready to accept $\mathrm{TJ}$ mechanisms to strengthen their own respective political agendas. In the process, however, the normative and institutional potentials of TJ have 
quite often been weakened. This is not to say that there is not acceptance of TJ principles in Bosnia, but overall, the voice of those who support TJ continues to be rather weak. There are of course many voices for peace and for a multicultural vision for Bosnia. However, we find that the ethnicized political environment, the harsh socio-economic reality, and the experience of the conflict have contributed to the persistent fears within the population, making the stories of division much more powerful than the stories of possible integration. Between the narratives of the uncertain future and the irreconcilable stories of the past, people are prone to find more meaning in the latter.

Social interactions at the local level are crucial to the analysis of the TJ and peace-building process. The reason that various international organizations in Bosnia have not been as successful in achieving the admittedly lofty goals of reconciliation is because most international representatives have underestimated the role the local population plays and have focused exclusively on the actions of various local ethnic and civic elites. However, the parallel existence of competing state and nation building projects in Bosnia and their dominance over externally-supported projects of reconciliation cannot be explained simply by relying on one overarching variable: Bosnian nationalist elites work towards their own selfish interests and against the interests of the people. Seventeen years of peace in Bosnia have shown that Bosnians have agency and that they know how to use it. The stories that people share are many and they compete with each other: some are inclusive, some less so, and some are downright exclusionist. Nevertheless, they always provide a meaningful frame of action that allows members of various local communities to cope with the exigencies of everyday life in Bosnia. Some of those narratives should not be dismissed simply because they are overtly nationalistic. Instead, a more suitable approach requires an analysis of what makes these stories so powerful and what are the objective political, social and economic constraints that continue to provide a fertile ground for their widespread support. Recognizing these narratives as meaningful, however, does not mean accepting their content. Rather, it is about analyzing the power such content has in framing actions at the local level.

\section{Notes}

1 Dejan Guzina is Associate Professor in Political Science at Wilfrid Laurier University in Waterloo (Ontario, Canada). His major research interests are in comparative democratization, state building and ethnic politics (email: dguzina@wlu.ca). Branka Marijan is a Ph.D. candidate in global governance at the Balsillie School of International Affairs (Wilfrid Laurier University). Her research interests are focused on issues of peacebuilding, citizenship and civil society in post-conflict countries (email: bmarijan@balsillieschool.ca). The authors would like to thank Kimberly Rygiel and the two anonymous reviewers for their helpful comments and suggestions.

2 The most detailed account to date on the number of casualties in the wars in the Former Yugoslavia in 1990s can be found in Tabeau, E. Conflict in Numbers: Casualties of the 1990s Wars in the Former Yugoslavia (1991-1999) published by the Helsinki Committee in Serbia, Belgrade. It can be accessed online: http://www.helsinki.org. 
rs/projects_cin.html. Belgrade Humanitarian Law Centre and Sarajevo Research and Documentation Center have jointly published the Book of Death in the Bosnian War (January 2013). Not surprisingly, The Association for Camp Inmates in Republika Srpska has immediately reacted by publicly dismissing the validity of its findings. Their reaction can be found in Maksimovic, D. (January 25, 2013). RS ne prihvata 'Bosansku knjigu mrtvih', Deutsche Welle, Retrieved on January 28, 2013 from http:// www.dw.de/rs-ne-prihvata-bosansku-knjigu-mrtvih/a-16549104.

\section{References}

Acharya, A. (2004). How ideas spread: Whose norms matter? Norm localization and institutional change in Asian regionalism. International Organization, 58 (2), 239-275.

Aptel, C. (2011). International and hybrid criminal tribunals: Reconciling or stigmatizing? In P. Arthur (Ed.), Identities in transition: Challenges for transitional justice in divided societies (pp. 149-186). Cambridge: Cambridge University Press.

Arthur, P. (2011). Fear of the future, lived through the past: Pursuing transitional justice in the wake of ethnic conflict. In P. Arthur (Ed.), Identities in transition: Challenges for transitional justice in divided societies (pp. 271-302). Cambridge: Cambridge University Press.

Brubaker, R. (1998). Myths and misconceptions in the study of nationalism. In J. Hall (Ed.), The state of the nation (pp. 272-306). Cambridge: Cambridge University Press.

Cassese, A. (2004). First Annual Report of the President of the ICTY to the United Nations General Assembly. Retrieved from http://www.icty.org/tabs/14/1.

Chandler, D. (2009). Hollow hegemony: Rethinking global politics, power and resistance. New York: Pluto Press.

Clark, J. N. (2009). The limits of retributive justice: Findings of an empirical study in Bosnia and Herzegovina. Journal of International Criminal Justice, 7(3), 463-487.

Delpla, I. (2007). In the midst of injustice: The ICTY from the perspective of some victims associations. In X. Bougarel, E. Helms \& G. Duijzings (Eds.), The new Bosnian mosaic: Identities, memories and moral claims in a post-war society (pp. 211-234). England: Ashgate.

Delpla, I., Bougarel, X., \& Fournel, J. L. (2012). Investigating Srebrenica: Institutions, facts, responsibilities. New York: Berghahn Books.

Fearon, J. D., \& Laitin, D. D. (2000). Social construction of ethnic identity. International Organization, 54(4), 845-877.

Fletcher, L. E. \& Weinstein, H. M., (2004). A world unto itself? The application of international justice in the former Yugoslavia. In E. Stover \& H.M. Weinstein (Eds.), My neighbour, my enemy: Justice and community in the aftermath of mass atrocity (pp. 29-48). Cambridge: Cambridge University Press.

Goldstone, R. J. \& Hamilton, R. J. (2008). Bosnia v. Serbia: Lessons from the encounter of the International Court of Justice with the International Criminal Tribunal for the Former Yugoslavia. Leiden Journal of International Law, 21, 95-112.

Halimovic, D. (2012, October 15). Haska sudjenja izmedju nade i razocarenja, Radio Slobodna Evropa, Retrived from http://www.slobodnaevropa.org/content/haska-sudjenja-izmedjunade-i -razocarenja/24740344.html.

Hamidovic, A. (2012). Pismo Milanu. Troyanac. Croatia: Menart.

ICTY. (1995). The Tribunal Welcomes the Parties' Commitment to Justice. Joint Statement by the President and the Prosecutor. The Hague, 24 November 1995 http://www.icty.org/sid/7220.

ICTY. (2012). President Meron's address before the United Nations General Assembly. The Hague, 15 October 2012. Retrieved from https://www.icty.org/sid/11113.

Jansen, S. (2007). Remembering with a difference: Clashing memories of Bosnian conflict in everyday life. In X. Bougarel, E. Helms \& G. Duijzings (Eds.), The new Bosnian mosaic: Identities, Memories and Moral Claims in a Post-War Society (pp. 193-210). England: Ashgate.

Jukic, E. M. (2012, December 10). Corruption halts Bosnia progress, Watchdog Says, Balkan Insight, Retrieved from http://www.balkaninsight.com/en/article/corruption-keeps-bosniadeep-in-crisis.

Kappler, S., \& Richmond, O. (2011). Peacebuilding and culture in Bosnia and Herzegovina: 
Resistance or emancipation. Security Dialogue 42(3), 261-278.

Karabeg, O. (2012, December 30). Mladi muzicari za BiH bez podjele i mrznje. Radio Slobodna Evropa. Retrieved from http://www.slobodnaevropa.org/content/mladost-mladi-muzicari-zabih-bez-podjela-i-mrznje/24811828.html.

Kebo, A. (2005, February 22). Regional report: Bosnian fury at Oric arrest, Institute for War and Peace Reporting (IWPR). Retrieved from: http://iwpr.net/report-news/regional-reportbosnian-fury-Oric-arrest.

Kymlicka, W. (2011). Transitional justice, federalism, and the accomodation of minority nationalism. In P. Arthur (Ed.), Identities in transition: Challenges for transitional justice in divided societies (pp. 303-333). Cambridge: Cambridge Unviersity Press.

Leebaw, B. A. (2008). The irreconcilable goals of transitional justice. Human Rights Quarterly, $30(1), 95-118$.

Mac Ginty, R. (2011). International peacebuilding and local resistance: Hybrid forms of peace. Great Britain: Palgrave Macmillan.

Meernik, J. (2005). Justice and peace? How the International Criminal Tribunal affects societal peace in Bosnia. Journal of Peace Research, 42(3), 271-289.

Nettelfield, L. J. (2010). Courting democracy in Bosnia and Herzegovina: The Hague Tribunal's impact in a postwar state. New York: Cambridge University Press.

Perry, V. (2009). A survey of reconciliation processes in Bosnia and Herzegovina: The gap between people and politics. In J. R. Quinn (Ed.), Reconciliation(s): Transitional justice in postconflict societies (pp. 174-206). Montreal and Kingston: McGill-Queen's University Press.

Prosecutor vs. Krstic, Appeals Chamber Judgment, April 19, 2004.

Pupavac, V. (2004). International therapeutic peace and justice in Bosnia. Social and Legal Studies, 13(3), 377-401.

Richmond, Oliver P. (2008). Reclaiming peace in international relations. Millennium: Journal International Studies, 36(3), 439-440.

Ross, M. H. (1997). Culture and identity in comparative political analysis. In M. I. Lichbach, \& A. Zuckerman (Eds.), Comparative Politics: Rationality, Culture, and Structure (pp. 42-80). Cambridge: Cambridge University Press.

Srebrenica Genocide Blog. (2009, October 9). How many people died in Bosnian war? Retrieved from http://srebrenica-genocide.blogspot.com/2009/10/how-many-people-died-in-bosnianwar.html.

Sriram C. L. (2010). Resolving conflicts and pursuing accountability: Beyond "justice vs. peace." In O.P. Richmond (Ed.), Palgrave Advances in Peacebuilding: Critical Developments and Approaches (pp. 279- 293). New York: Palgrave Macmillan.

Subotic, J. (2009). Hijacked justice: Dealing with the past in the Balkans. Ithaca, NY: Cornell University Press.

World Bank. (2012). South East Europe Regular Economic Report: From Double-Dip Recession to Accelerated Reform (No.3). Retrieved from http://www.worldbank.org/content/dam/ Worldbank/document/SEERER_3_Report_FINAL_eng.pdf

Zoglin, K. (2005). The future of war crimes prosecutions in the former Yugoslavia: Accountability or junk justice? Human Rights Quarterly, 27(1), 41-77. 